\title{
An Assessment of Grid-Charged Inverter-Battery Systems for Domestic Applications in Ghana
}

\author{
David A. Quansah, ${ }^{1,2}$ Muyiwa S. Adaramola, ${ }^{1}$ Isaac A. Edwin, ${ }^{2}$ and Emmanuel K. Anto ${ }^{2}$ \\ ${ }^{1}$ Renewable Energy Group, Department of Ecology and Natural Resource Management, Norwegian University of Life Sciences (NMBU), \\ Høgskoleveien 12, $1430 \AA$ As, Norway \\ ${ }^{2}$ The Energy Center, Kwame Nkrumah University of Science and Technology (KNUST), Kumasi, Ghana
}

Correspondence should be addressed to Muyiwa S. Adaramola; muyiwa.adaramola@nmbu.no

Received 31 March 2016; Accepted 15 May 2016

Academic Editor: Jayasundera M. S. Bandara

Copyright (C) 2016 David A. Quansah et al. This is an open access article distributed under the Creative Commons Attribution License, which permits unrestricted use, distribution, and reproduction in any medium, provided the original work is properly cited.

\begin{abstract}
Ghana, like many African countries, is currently facing power supply shortage, which has led to load shedding. To minimize the impact of the power crisis, options such as diesel and petrol generators, grid-charged battery-inverter systems (GBIS), and solar PV with battery storage (SPVS) have been used in residential and nonresidential contexts. In this paper, we develop analytical models to conduct a technical and economic comparison of GBIS and SPVS systems. Using average electricity tariff of $\$ 0.186$ for residential sector (excluding lifeline customers) we show that although initial cost of SPVS is higher, it costs $30 \%$ less than GBIS. We also show that losses associated with the GBIS are as high as $42 \%$ when viewed from a systems perspective and that some of its costs are externalized. We conclude by commending the Ghana Government's initiative of rolling out 200,000 residential rooftop solar systems and recommend an increase in system capacities as well as a similar programme for nonresidential facilities.
\end{abstract}

\section{Background}

In 2012, Ghana began shedding load because of power supply deficit. The immediate cause of the load shedding was the rapture in August 2012 of portions of the West African Gas Pipeline by the anchor of a ship in Togo [1-5]. The West African Gas Pipeline is a $678 \mathrm{~km}$ pipeline that transports gas from Escravos-Lagos in Nigeria to Benin, Togo, and terminates at Takoradi in Ghana (Figure 1), and it is designed to transport $800 \mathrm{MMscfd}$ of natural gas [5-7]. The rapture resulted in $300 \mathrm{MW}$ of natural gas based generation being lost [8] and although the pipeline was repaired by end of July 2013, other domestic and external factors kept Ghana's power generation significantly below system demand and in 2015 up to $600 \mathrm{MW}$ of load was being shed [4, 6, 9-11].

The history of Ghana's power sector shows that the country has experienced generation deficits at various points notably $1983,1997,2003 / 4$, and $2006 / 07$ [6, 12, 13], yet the crisis which began in 2012 stands out as the most protracted. To manage the situation, the electricity distribution utility company, the Electricity Company of Ghana (ECG), liaising with the transmission system operator (TSO) and power generation companies published a load-shedding programme, which seeks to keep National Interconnected Transmission System (NITS) stable and balanced. By February 2015, the load-shedding duration for various distribution zones was officially for periods of up to 12 hours [14] (Figure 2), though nonadherence to the schedule had been reported. The power supply situation has registered some improvement in 2016 due inter alia to additional capacity that was brought on board in 2015 [15].

Due to unreliable power supply (and load-shedding situation), electricity consumers-residential, nonresidential, and so forth-are forced to consider alternatives to meet their electricity needs. Some of the options include dieseland petrol-fuelled generators, grid-charged battery-inverter systems (GBIS), and solar PV with battery storage (SPVS). In the GBIS configuration, a battery bank is charged when the grid is on, and when it goes off, the battery, through the inverter, supplies power to designated equipment as shown schematically in Figure 3. 


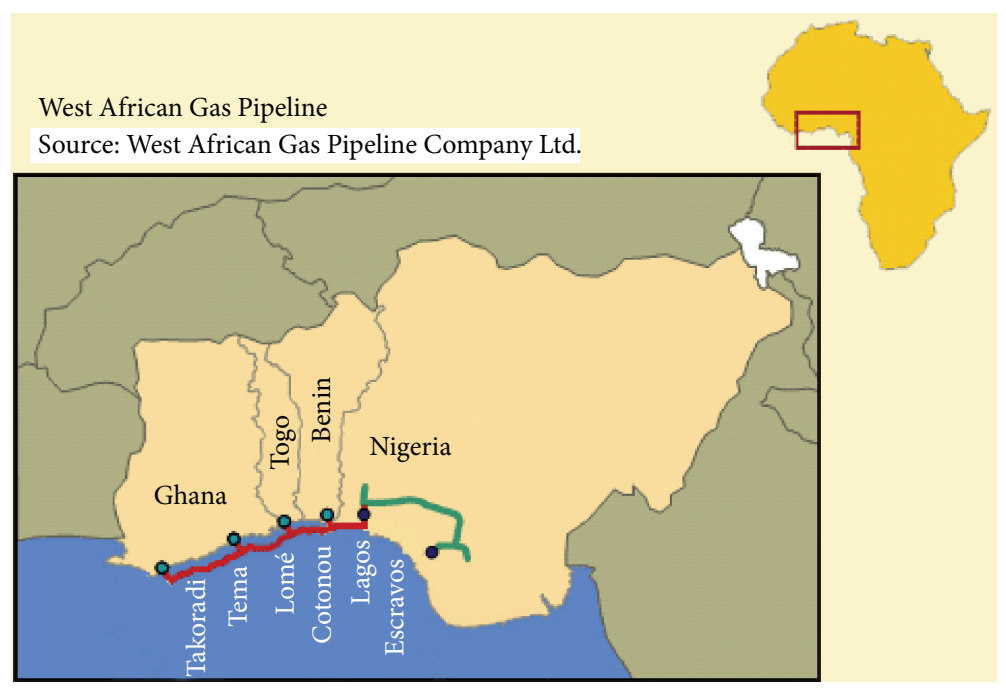

Figure 1: The West African Gas Pipeline [16].

\begin{tabular}{|c|c|c|c|c|c|c|c|}
\hline \multicolumn{8}{|c|}{$\begin{array}{l}\text { The Electricity Company of Ghana wishes to inform its cherished customers that due to generation shortfall it has become } \\
\text { necessary to publish this load shedding guide. } \\
\text { All Communities in the bracket are on loadshedding, but all or some may not go off depending on the quantum of power to be shed }\end{array}$} \\
\hline & $\begin{array}{l}\text { FRIDAY } \\
\text { 06/02/2015 }\end{array}$ & $\begin{array}{l}\text { SATURDAY } \\
07 / 02 / 2015\end{array}$ & $\begin{array}{c}\text { SUNDAY } \\
08 / 02 / 2015\end{array}$ & $\begin{array}{l}\text { MONDAY } \\
09 / 02 / 2015\end{array}$ & $\begin{array}{l}\text { TUESDAY } \\
10 / 02 / 2015 \\
\end{array}$ & $\begin{array}{c}\text { WEDNESDAY } \\
11 / 01 / 2015\end{array}$ & $\begin{array}{l}\text { THURSDAY } \\
12 / 02 / 2015\end{array}$ \\
\hline DAY $6 A M$ TO 7PM & $\mathrm{B} ;(\mathrm{A})$ & C; (B) & $\mathrm{A} ;(\mathrm{C})$ & $\mathrm{B} ;(\mathrm{A})$ & C; (B) & $\mathrm{A} ;(\mathrm{C})$ & B; (A) \\
\hline NIGHT 6 PM TO GAM & $\mathrm{A} ;(\mathrm{C})$ & B; (A) & C; (B) & $\mathrm{A} ;(\mathrm{C})$ & $\mathrm{B} ;(\mathrm{A})$ & C; (B) & $\mathrm{A} ;(\mathrm{C})$ \\
\hline & $\begin{array}{c}\text { FRIDAY } \\
13 / 02 / 2015\end{array}$ & $\begin{array}{l}\text { SATURDAY } \\
14 / 02 / 2015\end{array}$ & $\begin{array}{c}\text { SUNDAY } \\
15 / 02 / 2015\end{array}$ & $\begin{array}{l}\text { MONDAY } \\
16 / 02 / 2015\end{array}$ & $\begin{array}{l}\text { TUESDAY } \\
17 / 02 / 2015\end{array}$ & $\begin{array}{c}\text { WEDNESDAY } \\
18 / 01 / 2015\end{array}$ & $\begin{array}{l}\text { THURSDAY } \\
19 / 02 / 2015\end{array}$ \\
\hline DAY 6 AM TO 7PM & C; (B) & $\mathrm{A} ;(\mathrm{C})$ & $\mathrm{B} ;(\mathrm{A})$ & C; (B) & $\mathrm{A} ;(\mathrm{C})$ & B; (A) & C; (B) \\
\hline NIGHT 6 PM TO 6 AM & $\mathrm{B} ;(\mathrm{A})$ & $\mathrm{C} ;(\mathrm{B})$ & $\mathrm{A} ;(\mathrm{C})$ & $\mathrm{B} ;(\mathrm{A})$ & $\mathrm{C} ;(\mathrm{B})$ & $\mathrm{A} ;(\mathrm{C})$ & $\mathrm{B} ;(\mathrm{A})$ \\
\hline & $\begin{array}{c}\text { FRIDAY } \\
20 / 02 / 2015\end{array}$ & $\begin{array}{l}\text { SATURDAY } \\
21 / 02 / 2015\end{array}$ & $\begin{array}{c}\text { SUNDAY } \\
\text { 22/02/2015 }\end{array}$ & $\begin{array}{l}\text { MONDAY } \\
\text { 23/02/2015 }\end{array}$ & $\begin{array}{l}\text { TUESDAY } \\
24 / 02 / 2015 \\
\end{array}$ & $\begin{array}{c}\text { WEDNESDAY } \\
25 / 01 / 2015\end{array}$ & $\begin{array}{l}\text { THURSDAY } \\
26 / 02 / 2015\end{array}$ \\
\hline DAY 6 AM TO 7PM & $\mathrm{A} ;(\mathrm{C})$ & B; (A) & $\mathrm{C} ;(\mathrm{B})$ & $\mathrm{A} ;(\mathrm{C})$ & $\mathrm{B} ;(\mathrm{A})$ & C; (B) & $\mathrm{A} ;(\mathrm{C})$ \\
\hline NIGHT 6 PM TO 6 AM & C; (B) & $\mathrm{A} ;(\mathrm{C})$ & B; (A) & C; (B) & $\mathrm{A} ;(\mathrm{C})$ & $\mathrm{B} ;(\mathrm{A})$ & $\mathrm{C} ;(\mathrm{B})$ \\
\hline & $\begin{array}{c}\text { FRIDAY } \\
27102 / 2015\end{array}$ & $\begin{array}{l}\text { SATURDAY } \\
28 / 02 / 2015\end{array}$ & $\begin{array}{c}\text { SUNDAY } \\
01 / 03 / 2015\end{array}$ & $\begin{array}{l}\text { MONDAY } \\
\text { 02/03/2015 }\end{array}$ & $\begin{array}{l}\text { TUESDAY } \\
03 / 1 / 203 / 2015\end{array}$ & $\begin{array}{c}\text { WEDNESDAY } \\
04 / 03 / 2015\end{array}$ & $\begin{array}{l}\text { THURSDAY } \\
05 / 03 / 2015\end{array}$ \\
\hline DAY 6AM TO 7PM & $\mathrm{B} ;(\mathrm{A})$ & C; (B) & $\mathrm{A} ;(\mathrm{C})$ & $\mathrm{B} ;(\mathrm{A})$ & $\mathrm{C} ;(\mathrm{B})$ & $\mathrm{A} ;(\mathrm{C})$ & $\mathrm{B} ;(\mathrm{A})$ \\
\hline NIGHT 6PM TO 6 AM & $\mathrm{A} ;(\mathrm{C})$ & $\mathrm{B} ;(\mathrm{A})$ & $\mathrm{C} ;(\mathrm{B})$ & $A ;(C)$ & $\mathrm{B} ;(\mathrm{A})$ & C; (B) & $A ;(C)$ \\
\hline & $\begin{array}{c}\text { FRIDAY } \\
06 / 03 / 2015\end{array}$ & & & & & & \\
\hline DAY 6 AM TO 7PM & $\mathrm{C} ;(\mathrm{B})$ & & & & & & \\
\hline NIGHT 6 PM TO 6 AM & $\mathrm{B} ;(\mathrm{A})$ & & & & & & \\
\hline
\end{tabular}

Below is the list of Affected Areas. Customers should please identify their areas and consult the time table. Customers can also access the load shedding guide at our website: www.ecggh.com. For further enquiries, please call our Contact Centre on 0302-611611.

FIGURE 2: A load-shedding schedule published by the Electricity Company of Ghana [14].

Also, in response to the power crisis, the Government of Ghana in 2015 announced plans to roll out 200,000 rooftop solar systems with the aim of saving $200 \mathrm{MW}$ of power from the national grid $[9,15]$. In January 2016, the Energy Commission of Ghana announced details of the initiative [17]. The National Rooftop Solar Programme, as it is called, offers up to $500 \mathrm{~W}$ of solar modules for residential buildings that meet the following criteria [17]: beneficiary must

(i) change all lamps in their facility to LED lamps;

(ii) be willing to purchase BoS (Balance of System) components; (iii) agree that the installation of the BoS will be done before the supply/installation of the solar PV panels from the programme;

(iv) install only deep cycle batteries designed for solar PV systems;

(v) ensure that BoS meet the minimum standards set by Ghana Standards Authority (GSA);

(vi) use only solar PV installers licensed by the Energy Commission for all the installation works.

The main objective of this work is to examine the economic performance of GBIS system. In order to achieve 


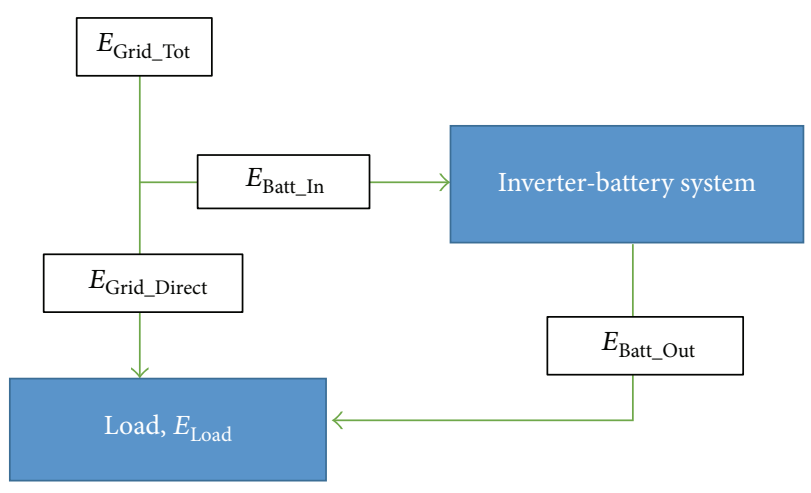

FIGURE 3: Schematic of a grid-charged battery-inverter system.

TABLE 1: Electricity tariffs for residential consumers in Ghana [20].

\begin{tabular}{lcc}
\hline $\begin{array}{l}\text { Residential } \\
\text { consumption band } \\
\text { (kWh) }\end{array}$ & GHp/kWh & US\$cent/kWh* \\
\hline $0-50$ & 33.56 & 8.84 \\
$51-300$ & 67.33 & 17.74 \\
$301-600$ & 87.38 & 23.02 \\
$601+$ & 97.09 & 25.58 \\
\hline Average & 71.34 & 18.79 \\
\hline
\end{tabular}

${ }^{*}$ Exchange rate of 1 US\$ $\rightarrow$ GH3.79 (11 Dec. 2015) [21].

this objective, in this paper, we developed analytical models for the technical and economic aspects of GBIS and SPVS and conduct a comparative assessment of the two end-user solutions to unstable grid power supply. Our analyses show that, for households consuming up to $600 \mathrm{kWh}$ per month, although the SPVS requires a higher initial cost, it is over 30\% cheaper on a life cycle cost when compared with the GBIS. The information presented in this study can help electricity users in Ghana to make an informed decision on which of the two systems analysed in this is more economically viable to meet their need.

\section{Method and Materials}

Table 1 shows the summary of key parameters and definitions used in modelling the two systems considered in this study. The modelling equations for the GBIS are derived in Section 2.1 while SPVS are presented in Section 2.2.

\subsection{Battery-Grid Model}

2.1.1. Energy Flows. In a given time duration, the total energy consumed by the load ( $\left.E_{\text {Load }}\right)$ would be the sum of the energy supplied directly by the grid ( $\left.E_{\text {Load_Grid }}\right)$ and the energy supplied through the battery-inverter system $\left(E_{\text {Batt_Out }}\right)$ and it is given as

$$
E_{\text {Load }}=E_{\text {Load_Grid }}+E_{\text {Batt_Out }} \text {. }
$$

Energies consumed by load through inverter-battery system and the grid system in a given year are given, respectively, as

$$
\begin{gathered}
E_{\text {Batt_Out }}=8760 \times \tau \times \chi \times D, \\
E_{\text {Load_Grid }}=8760 \times(1-\tau) \times D,
\end{gathered}
$$

where $\tau$ is the annual grid downtimes, as proportion (\%) of total yearly hours of 8760 hours; $\chi$ is the proportion of regular load (\%) that is powered by the battery-inverter system when grid is off; and $D$ is the average annual power demand (kW) and is estimated as

$$
D=\frac{E_{\text {Grid_Pre }}}{8760},
$$

where $E_{\text {Grid_Pre }}$ is the total annual energy requirement in $\mathrm{kWh}$ from grid (preinstallation), that is, if the entire load was supplied by electricity from the grid. The total amount of electricity taken from grid in year $t$ is written as

$$
E_{\text {Grid_Tot_t }}=E_{\text {Load_Grid }}+E_{\text {Batt_In } t \text {, }} \text {, }
$$

where $E_{\text {Batt_In_t }}$ is the annual energy input (kWh) to battery system in year $t$. $E_{\text {Batt_In_t }}$ is related to the output of the batteryinverter subsystem $\left(E_{\text {Batt_Out }}\right)$ by

$$
E_{\text {Batt_In } \_t}=\frac{E_{\text {Batt_Out }}}{\eta_{\text {Conv } \_t}},
$$

where $\eta_{\text {Conv } \_}(\%)$ is the combined efficiency of power conversion and storage system in year $t$. By incorporating (2), the preceding equation (6) may be rewritten as

$$
E_{\text {Batt_In } \_t}=\frac{8760 \times \tau \times \chi \times D}{\eta_{\text {Conv } \_t}} .
$$

Efficiency of power conversion and storage system in year $t$ may be expressed as

$$
\eta_{\text {Conv } \_}=\eta_{\text {Batt } \_t} \times \eta_{\text {Inv } \_} \text {, }
$$

where $\eta_{\text {Batt_t }}$ and $\eta_{\text {Inv_t }}$ are the efficiencies (\%) of battery and inverter-charging subsystems, respectively, in year $t$. Since the performance of the batteries and inverter-charging systems are not constant throughout the life of the project, the conversion efficiencies in year $t$ are computed as

$$
\begin{aligned}
\eta_{\text {Batt } t} & =\eta_{\text {Batt_1 }}\left[\alpha_{\text {Batt }}+1\right]^{(t-1)}, \\
\eta_{\text {Inv } \_} & =\eta_{\text {Inv_1 }}\left[\alpha_{\text {Inv }}+1\right]^{(t-1)},
\end{aligned}
$$

where $\eta_{\text {Batt_1 }}$ and $\eta_{\text {Inv_1 }}$ are, respectively, the initial efficiencies of the battery and inverter-charging subsystems while $\alpha_{\text {Batt }}$ and $\alpha_{\text {Inv }}$ are, respectively, the annual degradation rate of battery round-trip efficiency and the inverter-charging system efficiency. By combining (8), (9), and (10), the overall conversion-storage efficiency in year $t$ could be obtained as

$$
\begin{aligned}
& \eta_{\text {Conv } \_t}=\eta_{\text {Batt } \_1}\left[\alpha_{\text {Batt }}+1\right]^{(t-1)} \times \eta_{\text {Inv } \_1_{1}}\left[\alpha_{\text {Inv }}+1\right]^{(t-1)}, \\
& \eta_{\text {Conv } \_t}=\eta_{\text {Conv } \_1}\left[\alpha_{\text {Batt }}+1\right]^{(t-1)} \times\left[\alpha_{\text {Inv }}+1\right]^{(t-1)},
\end{aligned}
$$


where

$$
\eta_{\text {Conv_1 }}=\eta_{\text {Batt_1 }} \times \eta_{\text {Inv_1 }} \text {. }
$$

Equation (5) is rewritten by incorporating (7) and (11a)-(11b). The total annual electricity taken from the grid in year $t$ then becomes

$$
\begin{aligned}
E_{\text {Grid_Tot_t } t}= & 8760 \times(1-\tau) \times D \\
& +\frac{8760 \times \tau \times \chi \times D}{\eta_{\text {Conv }_{1}}\left[\alpha_{\text {Batt }}+1\right]^{(t-1)} \times\left[\alpha_{\text {Inv }}+1\right]^{(t-1)}} .
\end{aligned}
$$

Upon further simplification, it becomes

$$
\begin{aligned}
& E_{\text {Grid_Tot } t}=8760 \times D[(1-\tau) \\
& \left.+\frac{\tau \times \chi}{\eta_{\text {Conv_1 }}\left[\alpha_{\text {Batt }}+1\right]^{(t-1)} \times\left[\alpha_{\text {Inv }}+1\right]^{(t-1)}}\right] .
\end{aligned}
$$

The contribution of annual electricity (delivered to load) which comes from inverter-battery system is

$$
\gamma=\frac{E_{\text {Batt_Out }}}{E_{\text {Load }}} .
$$

The $\%$ increase in grid electricity consumption as a result of the introduction of the battery-inverter system is computed as

$$
\beta=1-\frac{E_{\text {Grid_Pre }}}{E_{\text {Grid_Tot_t }}} .
$$

2.1.2. Economics. The economics aspect of this modelling relates to the amount of annual electricity bill paid by the consumers. This amount comprises the cost of electricity supplied directly by the grid and that supplied by the battery. Hence, the annual electricity cost to consumer, $C_{\text {Load }}$ $(\$ / \mathrm{kWh})$, is given as

$$
C_{\text {Load }}=(1-\gamma) C_{\text {Grid_Elect }}+\gamma C_{\text {Load_Batt }} .
$$

The value of $C_{\text {Load_Batt }}$ is determined as the Levelized Cost of Electricity (LCOE) over the life of GBIS investment. The LCOE is a commonly used metric for assessing the financial and economic viability of energy technologies $[18,19]$. Since batteries life $\left(N_{1}\right)$ usually lasts shorter than that of inverters $\left(N_{2}\right)$, the life of the former, $N_{1}$, is chosen as the period for economic assessment, $T$. The $C_{\text {Load_Batt }}$ is then written as

$$
\begin{aligned}
C_{\text {Load_Batt }} & =\text { LCOE }=\frac{\text { NPV of Costs of the GBIS system }}{\text { NPV of Electricity Delivered to Load from Battery }}, \\
\text { LCOE } & =\frac{\text { Initial Costs }+ \text { NPV }(\mathrm{O} \& M)-\text { Salvage Value }}{\text { NPV of Electricity Delivered to Load from Battery }} \\
& =\frac{\text { Battery Capacity } \times \text { Unit Cost }+ \text { Inverter Capacity } \times \text { Unit Cost }+ \text { NPV }(\mathrm{O} \& M)-S_{\text {Inv }}}{\text { NPV of Electricity Delivered to Load from Battery }} .
\end{aligned}
$$

Battery capacity, $K_{\mathrm{Batt}}$, in $\mathrm{kWh}$, is determined as

$$
K_{\text {Batt }}=\frac{E_{\text {Load_Daily }} \times \chi \times D_{\text {Aut }}}{\text { DOD }},
$$

where DOD is the maximum battery depth of discharge (\%) and $D_{\text {Aut }}$ is the desired days of autonomy which is set to 1 day in this analysis, since the battery is used as backup for grid system. The inverter capacity, $K_{\text {Inv }}$, is determined as

$$
K_{\text {Inv }}=D \times \chi \times 1.25 \text {. }
$$

The average cost of electricity, which serves as input to the battery-inverter system, is treated as annual operation and maintenance cost $(\mathrm{O} \& \mathrm{M})$. Table 1 shows the current cost of electricity (tariff) for the residential consumers in Ghana. In addition to the tariffs shown in Table 1, electricity customers pay additional levies that include Value-Added Tax (VAT), monthly service charge, and other special-purpose levies determined from time to time by government.

At discount rate $r \%$, for an investment period $T$, the LCOE is finally given as

$$
\mathrm{LCOE}=\frac{C_{\text {Batt_Cost }} \times K_{\text {Batt }}+C_{\text {Inv_Cost }} \times K_{\text {Inv }}+\sum_{t=1}^{T}\left(\left(C_{\text {Grid_Elect }} \times E_{\text {Batt_In_t }}\right) /(1+r)^{t}\right)-S_{\text {Inv }}}{\sum_{t=1}^{T}\left(E_{\text {Batt_Out }} /(1+r)^{t}\right)},
$$


where $S_{\text {Inv }}$ is the salvage value of the inverter, defined as

$$
S_{\text {Inv }}=\left(\frac{N_{2}-T}{N_{2}}\right) \times C_{\text {Inv_Cost }} \times K_{\text {Inv }}
$$

and $E_{\text {Batt_out }}$ is defined in (6) and (7).

\subsection{PV-Inverter-Battery-Grid Model}

2.2.1. Energy Flows. An alternate configuration involves utility grid with solar PV and battery-inverter subsystems. The schematic of this configuration is shown in Figure 4.

The PV array size (in $\mathrm{kW}$ ) is estimated as

$$
P_{\text {Array }}=\frac{E_{\text {Load_Daily }} \times D_{\text {Aut }} \times \chi}{\text { PSH } \times \eta_{\text {Derate }} \times \eta_{\text {Conv_1 }}} .
$$

In this design, $\chi$ is set to $50 \%$ as the system is designed to meet half of the average daily load. In the case of the grid-battery system, the system was modelled as requiring an increasing amount of electricity input over the years to yield a constant energy required to service the load and to account for the deteriorating battery-inverter performance each year. The PV-Inverter-Battery system, however, is modelled as having a constant input from PV array and rather a declining output because of declining performance of battery-inverter subsystems. The annual output of the PV array, $E_{\text {In_PV }}$ (in $\mathrm{kWh}$ ), that is, input to the inverter-battery subsystem, is estimated as

$$
E_{\text {In_PV }}=P_{\text {Array }} \times \mathrm{PSH} \times 365 \times \eta_{\text {Derate }},
$$

where PSH is the peak sunshine hours and $\eta_{\text {Derate }}$ is the derating factor of the PV array. In addition, the output from the inverter-battery subsystem is given as

$$
E_{\text {Out_PV }}=E_{\text {In_PV }} \times \eta_{\text {Conv } \_t} \text {. }
$$

The inverter capacity, $K_{\text {Inv }}(\mathrm{kW})$, is estimated as per (20). The battery capacity remains unchanged and is sized according to (19).

2.2.2. Economics. The LCOE of electricity from this configuration is then computed as

$$
\mathrm{LCOE}=\frac{C_{\text {Batt_Cost }} \times K_{\text {Batt }}+C_{\text {Inv_Cost }} \times K_{\text {Inv }}+C_{\text {Mod_Cost }} \times P_{\text {Array }}+\text { NPV of O\&M Cost }-S}{\sum_{t=1}^{T}\left(E_{\text {Batt_Out }} /(1+r)^{t}\right)} .
$$

The O\&M cost is regarded as negligible in comparison with the other terms and is neglected in further analysis. $S$ is the salvage value. Since this analysis is being conducted over the life of the battery, $S$ comprises the salvage values of the inverter $\left(S_{\text {Inv }}\right)$ with useful life of $N_{2}$ years and the PV array $\left(S_{\mathrm{PV}}\right)$ with useful life of $N_{3}$ years. $S_{\text {Inv }}$ is determined as shown in (22), and similarly, $S_{\mathrm{PV}}$ is determined as shown below:

$$
\begin{aligned}
S_{\mathrm{PV}} & =\left(\frac{N_{3}-T}{N_{3}}\right) \times C_{\text {Mod_Cost }} \times P_{\text {Array }}, \\
S & =S_{\text {Inv }}+S_{\mathrm{PV}} .
\end{aligned}
$$

To compute the cost of electricity from PV-Battery system, (21) is modified to incorporate the additional cost of PV modules.

2.3. Model Input Parameters. Input parameters for the models developed are summarized in Table 2 with brief remarks as needed. With these parameters, the technical and economic performances of the GBIS and SPVS are carried out.

\section{Results and Discussion}

In this section, results of the analysis based on the analytical expressions derived in Sections 2.1 and 2.2 as well as input parameters presented in Section 2.3 are presented and discussed. The grid-battery-inverters system (GBIS) is presented in Section 3.1 while that of SPVS is presented in Section 3.2.

\subsection{Grid-Battery-Inverter System (GBIS)}

3.1.1. Technical Analysis. A reference scenario is defined as per Table 2 and entails grid-charged battery-inverter system designed to meet $50 \%(\chi=50 \%)$ of the load of a residential electricity customer consuming $600 \mathrm{kWh}$ per month (annual consumption of $7200 \mathrm{kWh}$ ) and annual grid outage hours of $50 \%$ ( $\tau=50 \%)$. Under these assumptions, on annual bases, the load will consume $5400 \mathrm{kWh}$ of electricity annually, that is, $3600 \mathrm{kWh}$ directly from the grid and $1800 \mathrm{kWh}$ through the battery system. Figure 5 presents energy through the battery-inverter subsystem and evolution of the conversion efficiencies over economic life of the battery ( 5 years).

The results show, in Figure 4, that conversion efficiencies of the battery and inverter-charger system decrease from $85 \%$ and $90 \%$, respectively, in year 1 to $81.7 \%$ and $86.5 \%$ in year 5 , thus resulting in subsystem conversion efficiency reducing from $76.5 \%$ in year 1 to $70.6 \%$ in year 5 (an average of $73.5 \%$ ). To service a constant annual load of $1800 \mathrm{kWh}$ over the economic life of the battery, the increasing losses due to reduction in the system's efficiency therefore need to be compensated for (half of the annual load (7200 kWh) is $3600 \mathrm{kWh}$. Since grid outage time, $\tau$, of $50 \%$ is used, this becomes $1800 \mathrm{kWh}$ ). Hence, energy input (taken from grid) increases from $2353 \mathrm{kWh}$ in year 1 (of which $23.5 \%$ constitute losses) to $2550 \mathrm{kWh}$ in year 5 (of which $29.4 \%$ constitute losses), an average of $26.5 \%$ conversion loss in the analysis period. It should be mentioned here that the wire losses are neglected in this analysis. Figure 6 shows the energy flows through the battery-inverter system in year 1 . 


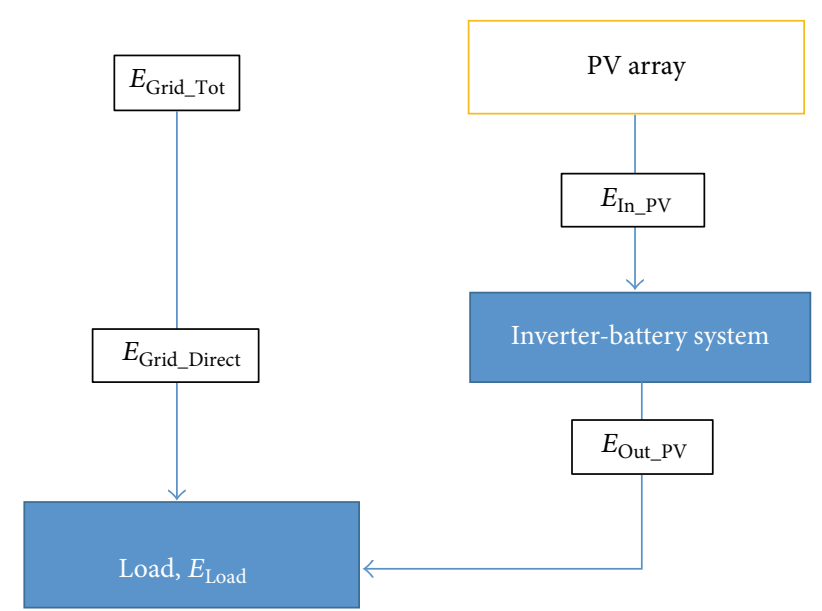

FIGURE 4: System configuration with PV array.

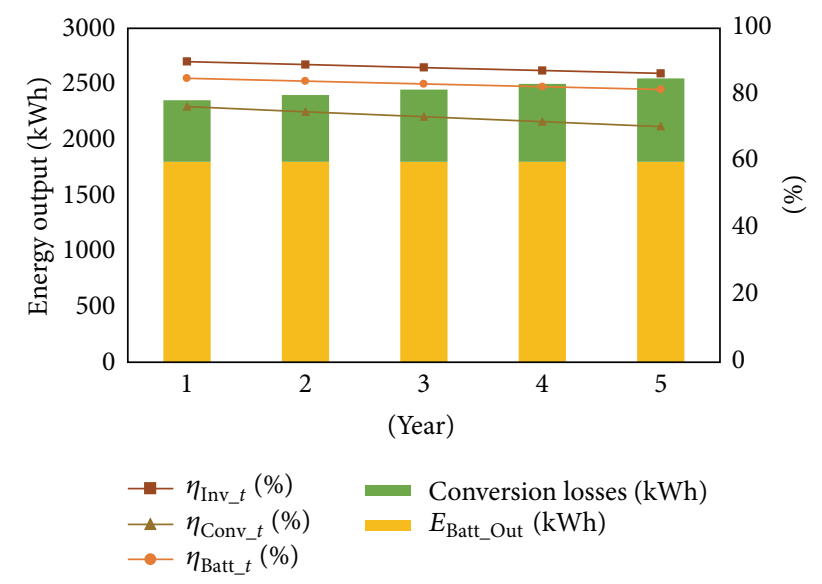

FIGURE 5: Energy through the battery-inverter system and conversion efficiencies.

The averaged transmission and distribution losses in Ghana over the past 15 years (from 2000 to 2014) are 21.6\% of generation [31,32]. These losses are dominated by losses in the distribution sector. The distribution sector losses, which comprise technical and commercial losses, average 25.7\% when considered as percentage of electricity purchased by the distribution utility. Viewed in the context of the National Interconnected System (NIS), the losses associated with the grid-charged battery-inverter systems increase significantly, reaching and surpassing $42 \%$.

3.1.2. Economic Analysis. At installed cost of $\$ 700 / \mathrm{kW}$ for inverter-charging system, battery cost of $\$ 250 / \mathrm{kWh}$, grid electricity tariff of $\$ 0.186 / \mathrm{kWh}$, and a discount rate of $5 \%$ (Table 2), the LCOE of electricity from the system under consideration as computed with (22) is estimated as $0.73 / \mathrm{kWh}$. The weighted average cost of servicing the load, $C_{\text {Load }}$, is $\$ 0.37 / \mathrm{kWh}$ (17) based on $\gamma=33.3 \%$ (15). The total life cycle cost of the system is estimated at $\$ 5,491.94$ comprising cost of inverter (3.3\%), battery (64.1\%), and O\&M (32.6\%) as shown in Figure 7.
From Figure 7, it is seen that the cost of the batteries dominates the net present costs followed by the O\&M cost. The O\&M cost represents the grid electricity tariff that is used to charge the battery bank. In estimating the O\&M cost, it is assumed that grid electricity tariff is constant throughout the economic life of the battery-inverter subsystem. The proportion of load that would run on the battery-inverter system, $\chi$, is determined at the design stage and it determines component sizes. The $\chi$ may, therefore, be considered fixed for the project life. On the other hand, the outage hours, as a percentage of the 8760 hours per year, $\tau$, could vary significantly. Figure 8 shows the variation of $\tau$, its effect on LCOE, and the weighted average cost of electricity, $C_{\text {Load }}$.

It is seen that the cost of electricity from the inverterbattery system approaches a minimum of $\$ 0.49 / \mathrm{kWh}$ as the outage hours reach $100 \%$, implying that $50 \%$ of the regular load is powered all year round and entirely by the inverter-battery system, thereby making maximal use of investment already made. At this point, the weighted average cost of electricity, $C_{\text {Load }}$, also reaches a maximum value of $\$ 0.49 / \mathrm{kWh}$. As the outage hours approach zero $(\tau=0 \%)$, the servicing of the load is accomplished predominantly by grid-supplied electricity and the weighted cost of electricity, $C_{\text {Load }}$, approaches its minimum of $\$ 0.30 / \mathrm{kWh}$ (determined by solving the regression equation). On the other hand, the cost of electricity from the inverter-battery system (LCOE) asymptotically approaches the vertical axis and increases exponentially as the denominator in (21) approaches zero.

To enable comparison with the PV-Battery system, which is designed to power half of the user's load for the year, sensitivity analysis on the grid-battery system is run at $\chi=50 \%$ and $\tau=100 \%$. Since the battery cost dominates the LCC (see Figure 6), a sensitivity of the LCOE to battery cost, ranging from a low of $\$ 150 / \mathrm{kWh}$ to a high of $\$ 350 / \mathrm{kWh}$, is run and presented in Figure 9. At battery cost of $\$ 150 / \mathrm{kWh}$, the LCOE (cost of electricity through the battery system) is $\$ 0.40 / \mathrm{kWh}$ and the batteries constitute $85.5 \%$ of initial cost and $34.9 \%$ of life cycle cost. The LCOE increases to $\$ 0.58 / \mathrm{kWh}$ at battery cost of $\$ 350 / \mathrm{kWh}$, where battery cost makes up $93.2 \%$ and $55.6 \%$ of initial cost and life cycle cost, respectively.

As utility tariffs constitute the main source of O\&M cost, the effect of increasing utility tariffs on LCOE of electricity from grid-battery configuration is analysed by running (21) with electricity tariffs ranging from $\$ 0.16 / \mathrm{kWh}$ to $\$ 0.30 / \mathrm{kWh}$. This range is selected to reflect prevailing tariff in Ghana for the residential category of electricity consumers. Figure 10 shows the relationship between discount rate (5$10 \%$ ), utility tariffs, and the LCOE. The LCOE increases from $\$ 0.45 / \mathrm{kWh}-\$ 0.49 / \mathrm{kWh}$ (at $\$ 0.16 / \mathrm{kWh}$ grid electricity price) to $\$ 0.65 / \mathrm{kWh}-\$ 0.68 / \mathrm{kWh}$ at electricity price of $\$ 0.30 / \mathrm{kWh}$. It should be noted that the LCOE of the GBIS will be higher if tariff increases and VAT and other charges are incorporated.

\subsection{Grid-Solar PV-Battery-Inverter System (SPVS)}

3.2.1. Technical Analysis. From (23) and the data in Table 2, the size of the array needed to meet half of the annual load of $3600 \mathrm{kWh}$ is estimated as $3.58 \mathrm{~kW}$. The inverter capacity is similarly determined from (26) as $0.51 \mathrm{~kW}$. The average 
TABLE 2: Input parameters for technical and economic models.

\begin{tabular}{|c|c|c|c|}
\hline Parameter definition & Variable & Value & Remark/reference \\
\hline Battery life (years) & $N_{1}$ & 5 & {$[22,23]$} \\
\hline Inverter-charger life (years) & $\mathrm{N}_{2}$ & 10 & Typical [24] \\
\hline Solar PV module life (years) & $N_{3}$ & 25 & Typical warranty period [25-27] \\
\hline Battery round-trip efficiency (initial), \% & $\eta_{\text {Batt_1 }}$ & $85 \%$ & {$[22]$} \\
\hline Battery round-trip efficiency in year $t, \%$ & $\eta_{\text {Batt_1 }}$ & - & Computed for various years (9) \\
\hline Battery depth of discharge, $\%$ & $\mathrm{DOD}_{\text {Batt }}$ & $70 \%$ & Authors' assumption \\
\hline Days of autonomy & $D_{\text {Aut }}$ & 1 & Authors' assumption \\
\hline Annual degradation rate of battery round-trip efficiency, \% & $\alpha_{\text {Batt }}$ & $1 \%$ & {$[22]$} \\
\hline Efficiency of inverter-charging system (initial), \% & $\eta_{\text {Inv_l }}$ & $90 \%$ & Assumed based on $80 \%$ average loading [28] \\
\hline Efficiency of inverter-charging system in year $t, \%$ & $\eta_{\text {Inv } \_t}$ & - & Computed for various years $(10)$ \\
\hline $\begin{array}{l}\text { Combined efficiency of power conversion and storage system } \\
\text { (initial), \% }\end{array}$ & $\eta_{\text {Conv_1 }}$ & $72 \%$ & Computed for year 1 (12) \\
\hline $\begin{array}{l}\text { Combined efficiency of power conversion and storage system in } \\
\text { year } t(\%)\end{array}$ & $\eta_{\text {Conv }-t}$ & - & Computed for various years (8) \\
\hline $\begin{array}{l}\text { Annual degradation rate of inverter-charging system efficiency } \\
\text { (initial), \% }\end{array}$ & $\alpha_{\text {Batt }}$ & $1 \%$ & Authors' assumption \\
\hline Total annual energy supplied by utility grid in year $t, \mathrm{kWh}$ & $E_{\text {Grid_Tot_t }}$ & - & Computed (14) \\
\hline $\begin{array}{l}\text { Total annual energy requirement from grid (preinstallation), } \\
\text { kWh }\end{array}$ & $E_{\text {Grid_Pre }}$ & 7200 & Based on monthly consumption of $600 \mathrm{kWh}$ \\
\hline Total annual energy requirement by load, kWh & $E_{\text {Load }}$ & - & Computed based on (1) \\
\hline Daily energy requirements of load, kWh & $E_{\text {Load_Daily }}$ & - & Computed \\
\hline Average annual power demand, $\mathrm{kW}$ & $D$ & - & Computed based on (4) \\
\hline Annual load (i.e., energy) directly supplied from grid, kWh & $E_{\text {Load_Grid }}$ & - & Computed (3) \\
\hline Annual energy supplied to load from battery system, kWh & $E_{\text {Batt_Out }}$ & - & Computed $(2)$ \\
\hline Annual energy input to battery system in year $t, \mathrm{kWh}$ & $E_{\text {Batt_In } \_t}$ & - & Computed for various years (6) \\
\hline Cost of electricity from grid, $\$ / \mathrm{kWh}$ & $C_{\text {Grid_Elect }}$ & 0.18 & Table $2[20]$ \\
\hline Economic life of investment, years & $T$ & 5 & Based on assumed battery life \\
\hline Unit installed cost of battery, $\$ / \mathrm{kWh}$ & $C_{\text {Batt_Cost }}$ & 250 & Market prices in Ghana [29] and from [22] \\
\hline Capacity of battery, kWh & $K_{\text {Batt }}$ & 28.18 & Computed (19) \\
\hline Unit installed cost of inverter and charging system, $\$ / \mathrm{kW}$ & $C_{\text {Inv_Cost }}$ & 700 & Market data in Ghana [29] \\
\hline Capacity of inverter, $\mathrm{kW}$ & $K_{\text {Inv }}$ & 0.51 & Computed based on (20) and (26) \\
\hline Discount rate, $\%$ & $r$ & $5 \%$ & Authors' assumption (tested for sensitivity) \\
\hline $\begin{array}{l}\text { Annual grid downtimes, as proportion of total yearly hours } \\
\text { (8760 hours), \% }\end{array}$ & $\tau$ & $50 \%$ & Based on published load-shedding schedule [14] \\
\hline Proportion of regular load $(\mathrm{kW})$ powered when grid is off, \% & $\chi$ & $50 \%$ & Authors' assumption \\
\hline $\begin{array}{l}\text { Proportion of annual load supplied through battery-inverter } \\
\text { system }\end{array}$ & $\gamma$ & - & Computed based on (17) \\
\hline Salvage value, $\$$ & $S$ & - & Computed (22), (27), and (28) \\
\hline Peak sunshine hours, h/day & PSH & 4.5 & Typical for Ghana [30] \\
\hline Array derating factor & $\eta_{\text {Derate }}$ & $80 \%$ & Authors' assumption \\
\hline Array size, $\mathrm{kW}$ & $P$ & - & Computed $(23)$ \\
\hline PV module cost, $\$ / \mathrm{kW}$ & $C_{\text {Mod_Cost }}$ & 2000 & Typical values for Ghana [29] \\
\hline
\end{tabular}

annual demand is $820 \mathrm{~W}$ (determined by (4)) and half of this $(410 \mathrm{~W})$ is expected to be powered by the solar PV system. The inverter is sized to handle $125 \%$ of this load. The annual input to the inverter-battery system from the PV array (as determined by (24)) and the yearly output from the inverterbattery system after conversion losses (determined by (25)) are shown in Figure 11. As a result of deterioration in the performance of the battery-inverter subsystem, conversion losses lead to decline in output to load, from year $1(3600 \mathrm{kWh})$ to year 5 (3322 kWh). Again, the wire losses are neglected in this analysis. Figure 12 shows the energy flows through the SPVS in year 1 . 


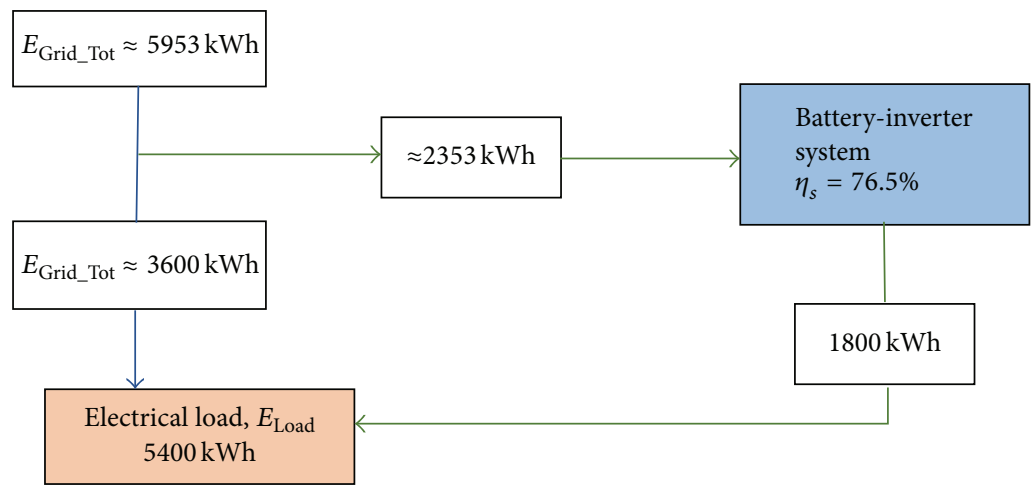

FiguRE 6: Energy flows through the grid-battery-inverter system in year 1.

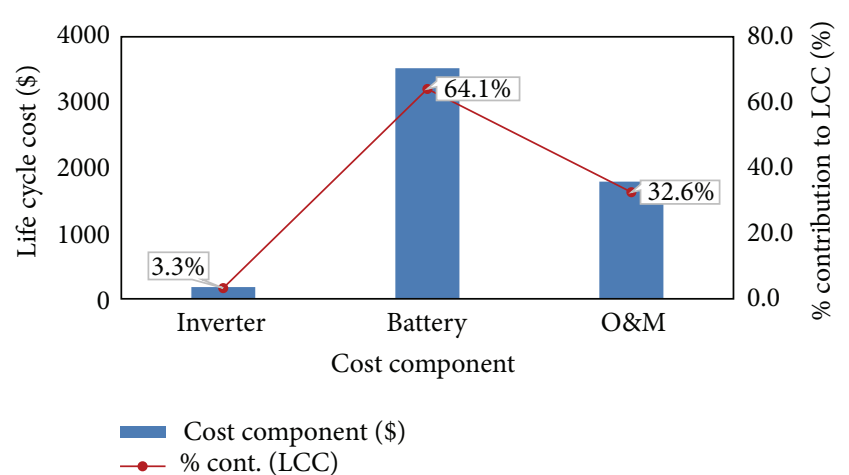

FIgURE 7: Present value of cost components of the grid-batteryinverter system.

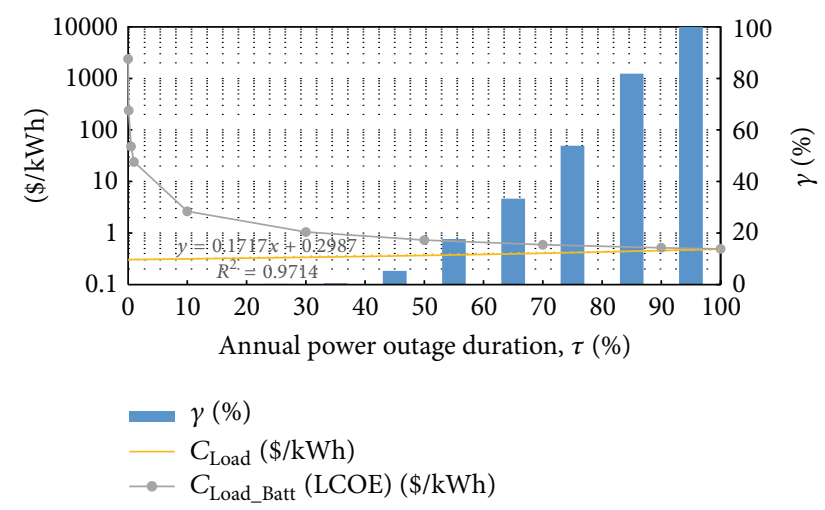

FIGURE 8: Evolution of LCOE and weighted cost of electricity with outage hours.

3.2.2. Economics Analysis. The LCOE of the PV-BatteryInverter subsystem is obtained using (27) and data presented in Table $2\left(\chi=50 \%, C_{\text {Mod_Cost }}=\$ 2000 / \mathrm{kW}, r=5 \%\right.$, etc.) as $\$ 0.34 / \mathrm{kWh}$ and a weighted cost of electricity $\$ 0.26 / \mathrm{kWh}$. This compares favourably with the grid-battery-inverter system meeting $50 \%$ of regular load at $\tau=100 \%$, where $\mathrm{LCOE}=C_{\mathrm{Load}}$ $=\$ 0.49 / \mathrm{kWh}$. As shown in Figure 13, the cost structure of the PV-Battery option is dominated by the cost of solar PV modules (almost 65\%) when considered in terms of initial

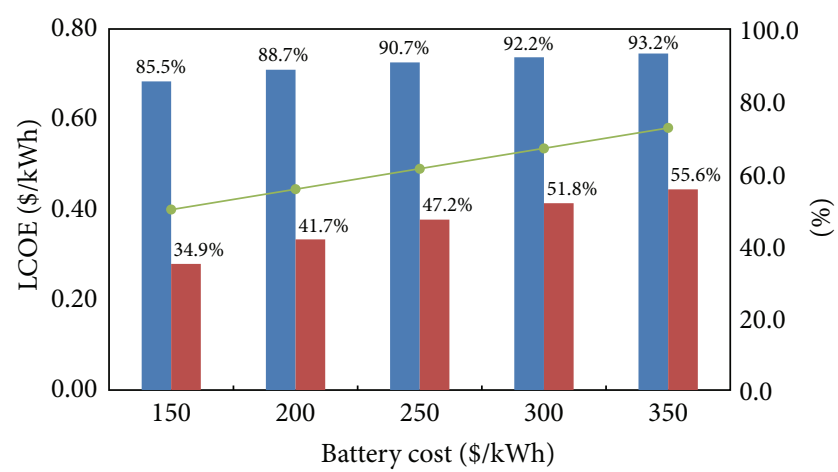

$\%$ of initial cost
$\%$ of life cycle cost

$\because \operatorname{LCOE}(\$ / \mathrm{kWh})$

FIGURE 9: Effect of battery cost on LCOE.

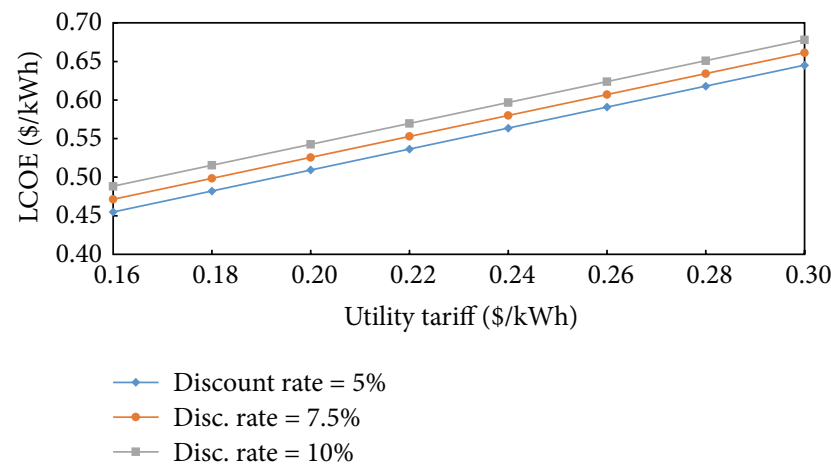

FIGURE 10: Effect of utility tariff on the LCOE of the battery-inverter system.

cost. The battery cost however dominates on a life cycle cost basis (68.6\%).

Figure 14 shows the sensitivity of LCOE to battery cost. It can be observed from this that the LCOE increases from $\$ 0.25 / \mathrm{kWh}$ (when battery cost is $\$ 150 / \mathrm{kWh}$ ) to $\$ 0.44 / \mathrm{kWh}$ (at battery cost of $\$ 350 / \mathrm{kWh}$ ). Similarly, the cost of battery as a percentage of initial cost and life cycle cost increases rises from $21.9 \%$ and $56.7 \%$, respectively, at battery cost of 


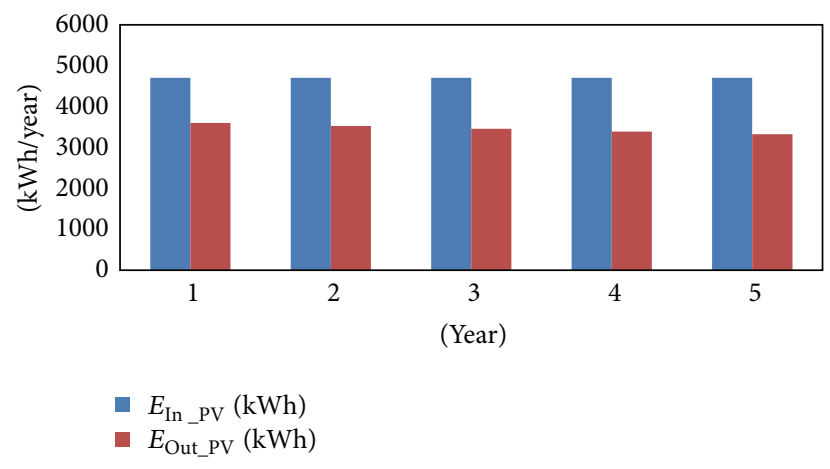

Figure 11: Energy output through the PV-Inverter-Battery subsystems.

$\$ 150 / \mathrm{kWh}$, and reaches $39.6 \%$ and $75.4 \%$ at battery cost of $\$ 350 / \mathrm{kWh}$.

Under the National Rooftop Solar Programme of Ghana, capital subsidy is granted on solar modules to qualified residential applicants (and in the form of free solar modules). Figure 15 shows the effect that such an intervention (or similar) could have on the cost of electricity from the SPVS. It is seen that the LCOE declines from $\$ 0.34 / \mathrm{kWh}$ under conditions of no support ( $0 \%$ subsidy) to $\$ 0.25 / \mathrm{kWh}$ when $100 \%$ support is provided on the cost of modules. Similarly, the average cost of electricity supply to loads declines from $\$ 0.26 / \mathrm{kWh}$ to $\$ 0.22 / \mathrm{kWh}$.

Solar irradiance varies across the country. As a tropical country, Ghana has abundant solar energy resources. The annual daily averaged global solar irradiation ranges from $3.1 \mathrm{kWh} / \mathrm{m}^{2}$ along the coastal region to $6.5 \mathrm{kWh} / \mathrm{m}^{2}$ in the northern region. The effect of this variation on LCOE and weighted average cost $C_{\mathrm{Load}}$ is shown in Figure 16. The LCOE declines from $\$ 0.34 / \mathrm{kWh}$ to $\$ 0.31 / \mathrm{kWh}$ as the irradiance increases from 4.5 hours of peak sunshine to 6.5 hours. $C_{\text {Load }}$ similarly decreases slightly from $\$ 0.26 / \mathrm{kWh}$ to $\$ 0.25 / \mathrm{kWh}$. Hence, this system will be more economically viable in the northern region of Ghana.

\section{Conclusions}

In this paper, we have assessed the technical and economic issues involved in the use of grid-charged batteryinverter system as end-user solutions to load-shedding and unreliable electricity supply as pertaining to Ghana and many other African countries. The assessment is done for a typical home that consumes an average of $600 \mathrm{kWh}$ a month ( $7200 \mathrm{kWh}$ p.a.), representing the highest band of the residential category and who wish to serve $50 \%$ of load when grid is down. The grid outage duration $(\tau)$ is considered to be up to 12 hours a day (i.e., $\tau=50 \%$ ) based on loadshedding schedule published by the Electricity Company of Ghana in 2015. $\tau$ is itself a varying quantity and the LCOE model is run for different scenarios of $\tau$, that is, when grid goes off completely $(\tau=100 \%)$ and as the grid becomes more stable (as $\tau$ approaches 0 ). This configuration (the gridcharged battery-inverter system, GBIS) has been compared with an alternative approach that uses solar PV with storage
(SPVS) facility and designed to meet half (50\%) of the user's regular load.

(i) The battery-inverter subsystem conversion efficiency averages $73.5 \%$ over the analysis period, implying an average loss of $26.5 \%$ of electricity drawn from the grid. When considered in the light of transmission and distribution losses in Ghana (which average $21.6 \%$ ), the figure rises beyond $40 \%$ of electricity generated, clearly showing the extent of dissipation of electricity that these systems bring about.

(ii) The results show an LCOE of $\$ 0.73 / \mathrm{kWh}$ for electricity supplied through the grid-battery system in the reference scenario $(\tau=50 \%, \chi=50 \%)$ decreases to $\$ 0.49 / \mathrm{kWh}$ when the system is utilized at maximum capacity (meeting $50 \%$ of load all year round). The weighted average cost of servicing the load, $C_{\text {Load }}$, is $\$ 0.37 / \mathrm{kWh}$ in the reference scenario and increases to $\$ 0.49 / \mathrm{kWh}$ at $\tau=100 \%$.

(iii) As outage hours approach zero (asymptotically), LCOE of grid-battery electricity starts to increase exponentially (reaching $\$ 24 / \mathrm{kWh}$ at $\tau=1 \%$ and $\$ 237.77 / \mathrm{kWh}$ at $\tau=0.1 \%)$. At this point, the weighted cost $C_{\text {Load }}$ reaches a minimum of $\$ 0.30 / \mathrm{kWh}$. As the grid becomes stable, the inverter-battery system risks becoming a stranded asset. It should be noted that, considering the significant T\&D losses incurred in the National Interconnected System (NIS) in delivering a unit of electricity to the consumer, significant cost in this configuration is likely to be externalized, including emissions cost.

(iv) The PV-Battery option shows an LCOE of $\$ 0.34 / \mathrm{kWh}$ and a weighted cost of $\$ 0.26 / \mathrm{kWh}$ of electricity supply to the load, $C_{\text {Load }}$. This compares favourably with LCOE of $\$ 0.49 / \mathrm{kWh}$ and $C_{\text {Load }}$ of $\$ 0.37 / \mathrm{kWh}$ for the grid-battery system.

(v) This makes the PV-Battery system $30 \%$ cheaper when compared with the configuration, which draws electricity from the grid to charge batteries. As peak sunshine hours increase to 6.5 hours, pertaining to the northern parts of Ghana, the LCOE and $C_{\text {Load }}$ decrease from $\$ 0.34 / \mathrm{kWh}$ and $\$ 0.26 / \mathrm{kWh}$, respectively, to $\$ 0.31 / \mathrm{kWh}$ and $\$ 0.25 / \mathrm{kWh}$, making the cost of solar PV-based system about $37 \%$ cheaper at this point. The cost advantage of PV-based option against the grid-based system is strengthened further if tariff increases are taken into account.

It should be noted, however, that, in spite of the cost advantage of the solar PV option, it requires significantly higher initial investment cost compared with the grid-charged batteryinverter option. The National Rooftop Solar Programme in Ghana is therefore one of the initiatives that could lower such barriers. Batteries, inverters, and PV modules come in discrete capacities and not a continuum of capacities as assumed in the models. In practical design considerations, available capacities that most closely match the user's needs are selected for installation. 


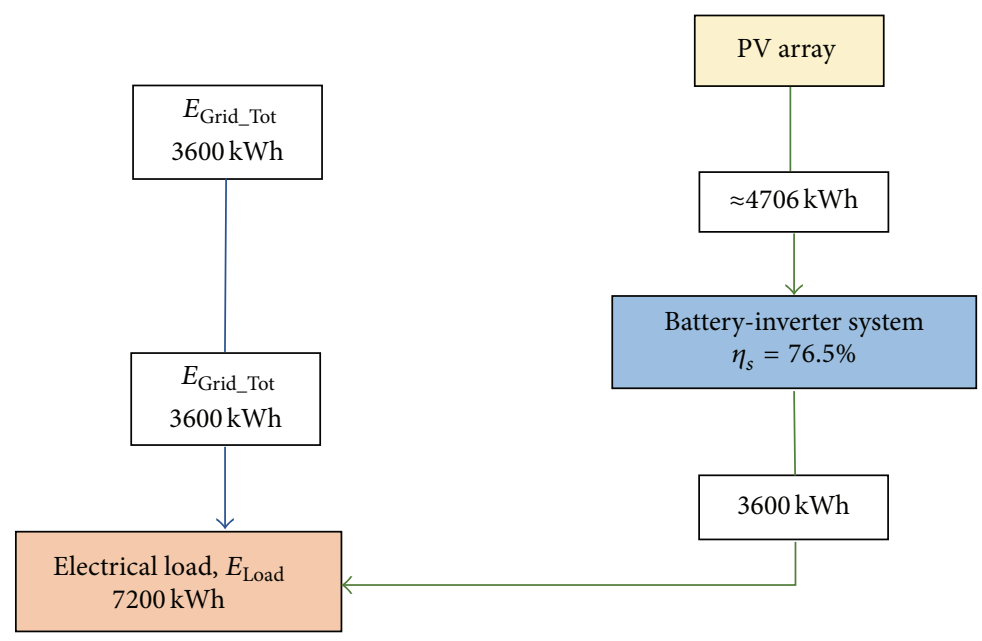

FIGURE 12: Energy flows through the SPVS in year 1.

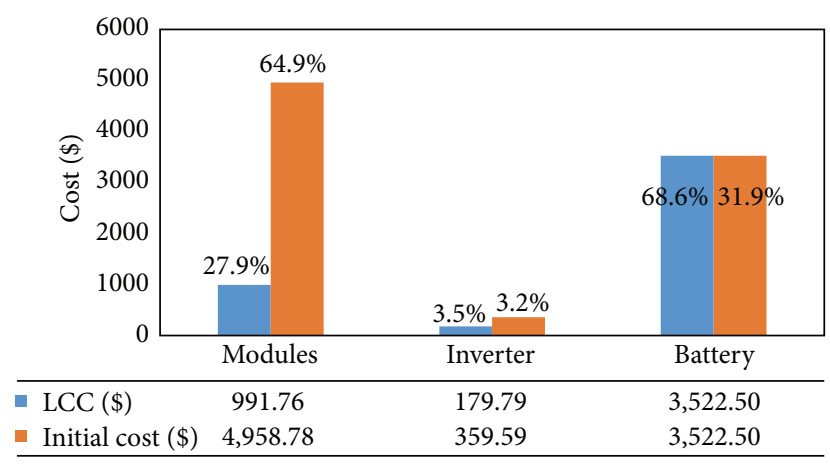

FIgURE 13: Cost distribution of solar PV-Battery-Inverter subsystem.

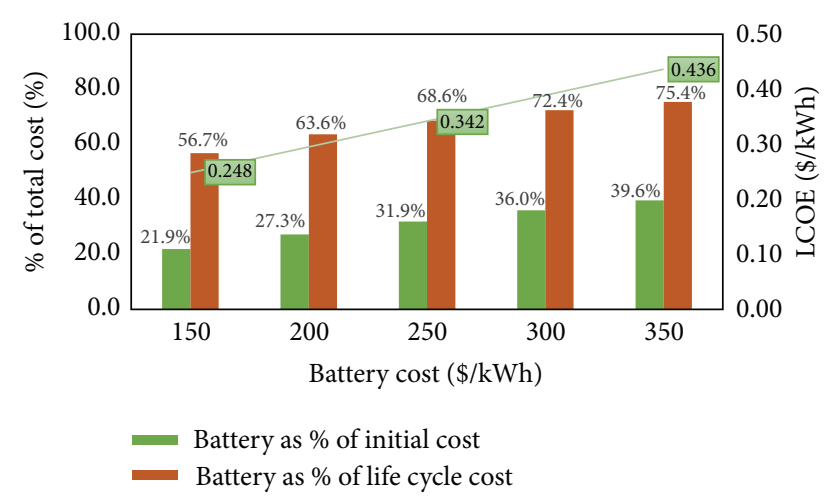

FIGURE 14: Effect of initial cost variation on LCOE and weighted cost.

\section{Competing Interests}

The authors declare that there is no conflict of interests regarding the publication of this paper.

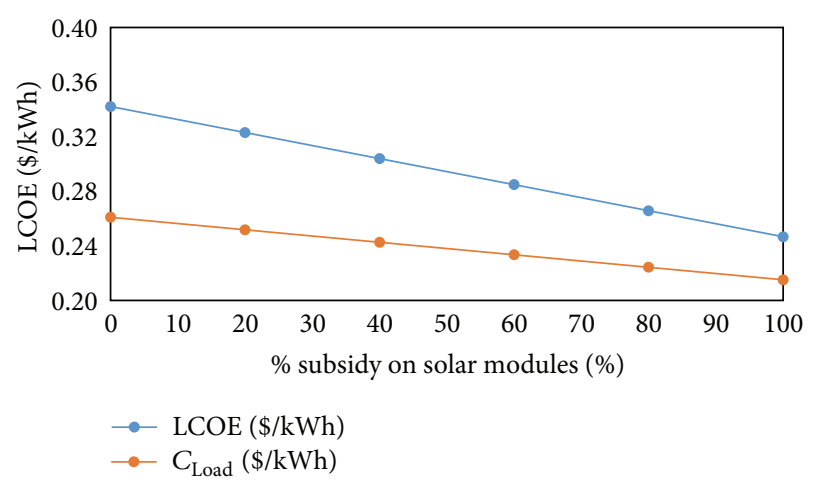

FIGURE 15: Effect of solar module capital subsidy on electricity cost.

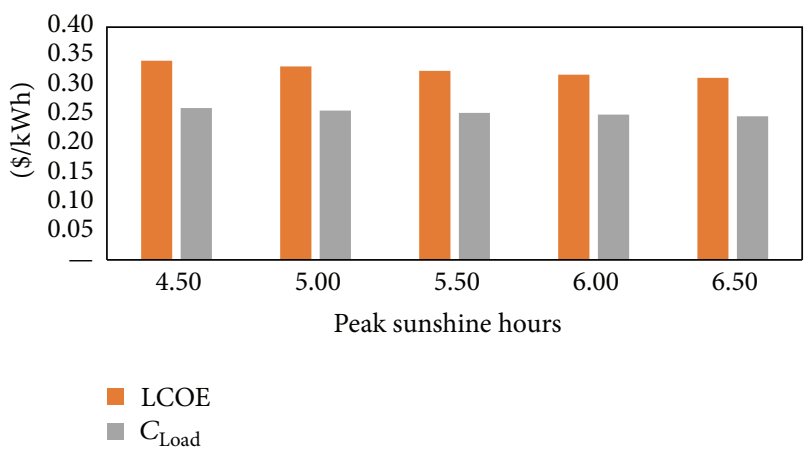

FIGURE 16: Effect of global solar radiation on LCOE of PV-Battery and weighted cost of electricity.

\section{Acknowledgments}

The authors thank the Norwegian Agency for Development Cooperation (NORAD) for supporting research collaboration between KNUST and NMBU through the EnPe programme. 


\section{References}

[1] K. J. Hancock, "Energy regionalism and diffusion in Africa: how political actors created the ECOWAS center for renewable energy and energy efficiency," Energy Research \& Social Science, vol. 5, pp. 105-115, 2015.

[2] Energy Commission, 2013 Energy (Supply and Demand) Outlook for Ghana, Energy Commission, Accra, Ghana, 2013.

[3] Volta River Authority, Fifty First Annual Report \& Accounts 2012, Volta River Authority, Accra, Ghana, 2013.

[4] World Bank, "Report No: ICR88918: Implementation Completion and Results Report (Guarantee No. B-006-0-GH) on a Partial Risk Guarantee in the Amount of US\$50.00 Million to the Republic of Ghana for the West African Gas Pipeline Project," June 2014, http://www-wds.worldbank.org/external/ default/WDSContentServer/WDSP/IB/2014/07/03/000016351_ 20140703141218/Rendered/INDEX/889180ICR0P0820IC0disclosed07020140.txt.

[5] J. Fritsch and R. Poudineh, "Gas-to-power market and investment incentive for enhancing generation capacity: an analysis of Ghana's electricity sector," Energy Policy, vol. 92, pp. 92-101, 2016.

[6] S. Gyamfi, M. Modjinou, and S. Djordjevic, "Improving electricity supply security in Ghana-the potential of renewable energy," Renewable and Sustainable Energy Reviews, vol. 43, pp. 1035-1045, 2015.

[7] West African Gas Pipeline Company, “About the pipeline," 2016, http://www.wagpco.com/index.php?option=com_content\&view $=$ article\&id $=122 \&$ Itemid $=84$ \&lang $=$ en.

[8] Ghana Business News, New Load Shedding Schedule on Tuesday-GRIDCo, 2012, https://www.ghanabusinessnews.com/ 2012/09/03/new-load-shedding-schedule-on-tuesday-gridco/.

[9] Government of Ghana, State of the Nation Address 2015, 2015.

[10] Energy Global, "West African Gas Pipeline Co. has restarted the West African Gas Pipeline," July 2013, http://www.energyglobal .com/pipelines/business-news/19072013/West_African_Gas_Pipeline_restarts/.

[11] Ghana Oil Watch, West Africa Gas Pipeline Company (WAPCo) Ready to Run at Full Capacity, 2013, http://ghanaoilwatch.org/ index.php/ghana-oil-and-gas-news/3362-west-africa-gas-pipeline-company-wapco-ready-to-run-at-full-capacity.

[12] F. Kemausuor, G. Y. Obeng, A. Brew-Hammond, and A. Duker, "A review of trends, policies and plans for increasing energy access in Ghana," Renewable and Sustainable Energy Reviews, vol. 15, no. 9, pp. 5143-5154, 2011.

[13] Kwame Nkrumah University of Science and Technology, Energy Crisis in Ghana: Drought, Technology or Policy?Edited by A. Brew-Hammond and F. Kemausuor, Kwame Nkrumah University of Science and Technology, Kumasi, Ghana, 2007.

[14] Electricity Company of Ghana, Load-Shedding Guide, 2015, http://www.ecgonline.info/images/Publication/Feb._2015_Load_ Shedding_Guide.pdf.

[15] Government of Ghana, The Budget Statement and Economic Policy of the Government of Ghana for 2016 Financial Year, 2015.

[16] US EIA, "Nigeria-LNG and pipeline exports," February 2015, https://www.eia.gov/beta/international/analysis.cfm?iso=NGA.

[17] Energy Commission, National Rooftop Solar Programme, Energy Commission, Accra, Ghana, 2016, http://www.energycom.gov.gh/news/122-application-form-for-rooftop-solar-programme-residential-applicant.
[18] K. Branker, M. J. M. Pathak, and J. M. Pearce, "A review of solar photovoltaic levelized cost of electricity", Renewable and Sustainable Energy Reviews, vol. 15, no. 9, pp. 4470-4482, 2011.

[19] S. B. Darling, F. You, T. Veselka, and A. Velosa, "Assumptions and the levelized cost of energy for photovoltaics," Energy and Environmental Science, vol. 4, no. 9, pp. 3133-3139, 2011.

[20] PURC, Publication of Electricity Tariffs, Public Utilities Regulatory Commission (Purc), Accra, Ghana, 2015.

[21] Bank of Ghana, "US DOLLAR Daily Forex Interbank Rates (Friday 11th December, 2015) -Day's Weighted Average Rate," Bank of Ghana, 2015, https://bog.gov.gh/index.php?option=com wrapper\&view=wrapper\&Itemid $=298$.

[22] X. Luo, J. Wang, M. Dooner, and J. Clarke, "Overview of current development in electrical energy storage technologies and the application potential in power system operation," Applied Energy, vol. 137, pp. 511-536, 2015.

[23] A. F. Crossland, O. H. Anuta, and N. S. Wade, "A sociotechnical approach to increasing the battery lifetime of offgrid photovoltaic systems applied to a case study in Rwanda," Renewable Energy, vol. 83, pp. 30-40, 2015.

[24] J. Flicker, PV Inverter Performance and Component-Level Reliability, National Renewable Energy Laboratory (NREL), Golden, Colo, USA, 2014.

[25] Trina Solar, 25 Year Insurance Backed Warranty, 2014.

[26] Kyocera, Limited Warranty for Kyocera Photovoltaic Module(s), Kyocera, 2013.

[27] M. Bortolini, M. Gamberi, A. Graziani, and F. Pilati, "Economic and environmental bi-objective design of an off-grid photovoltaic-battery-diesel generator hybrid energy system," Energy Conversion and Management, vol. 106, pp. 1024-1038, 2015.

[28] M. Bianchi, L. Branchini, C. Ferrari, and F. Melino, "Optimal sizing of grid-independent hybrid photovoltaic-battery power systems for household sector," Applied Energy, vol. 136, pp. 805816, 2014.

[29] S. Denkyira, Techno-Economic Analysis of Stand Alone Solar PV Systems for Remote Base Stations in Ghana, 2015.

[30] E. Quansah, L. K. Amekudzi, K. Preko et al., "Empirical models for estimating global solar radiation over the Ashanti region of Ghana," Journal of Solar Energy, vol. 2014, Article ID 897970, 6 pages, 2014.

[31] Energy Commission, Energy Statistics, Energy Commission, Accra, Ghana, 2014.

[32] Energy Commission, National Energy Statistics 2005-2014 (updated Dec 2015), Energy Commission, Accra, Ghana, 2005. 

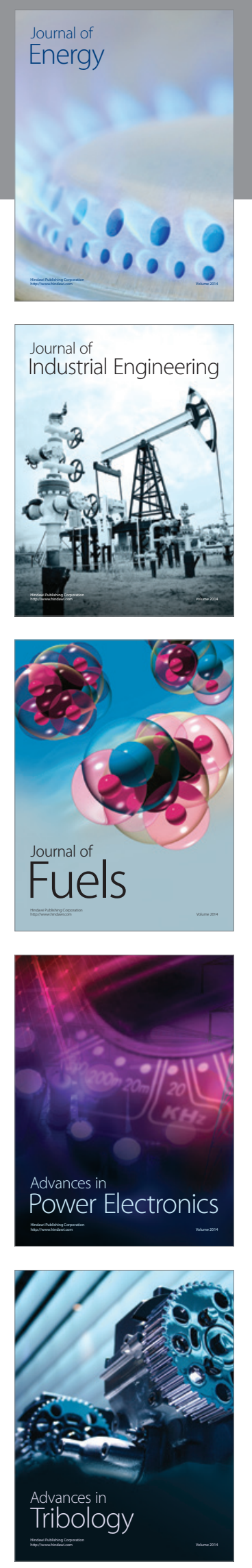
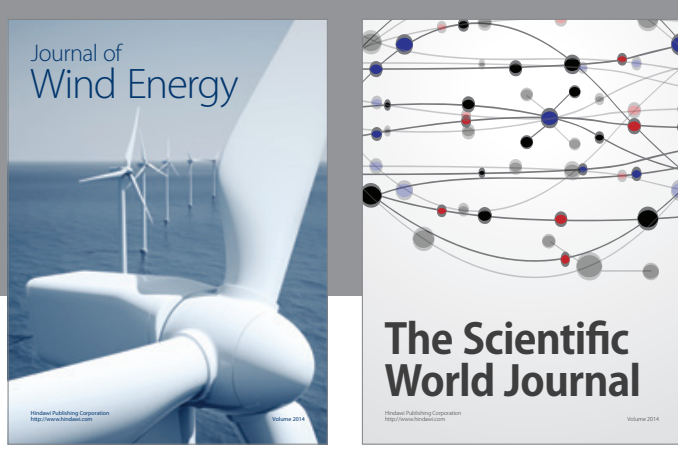

The Scientific World Journal
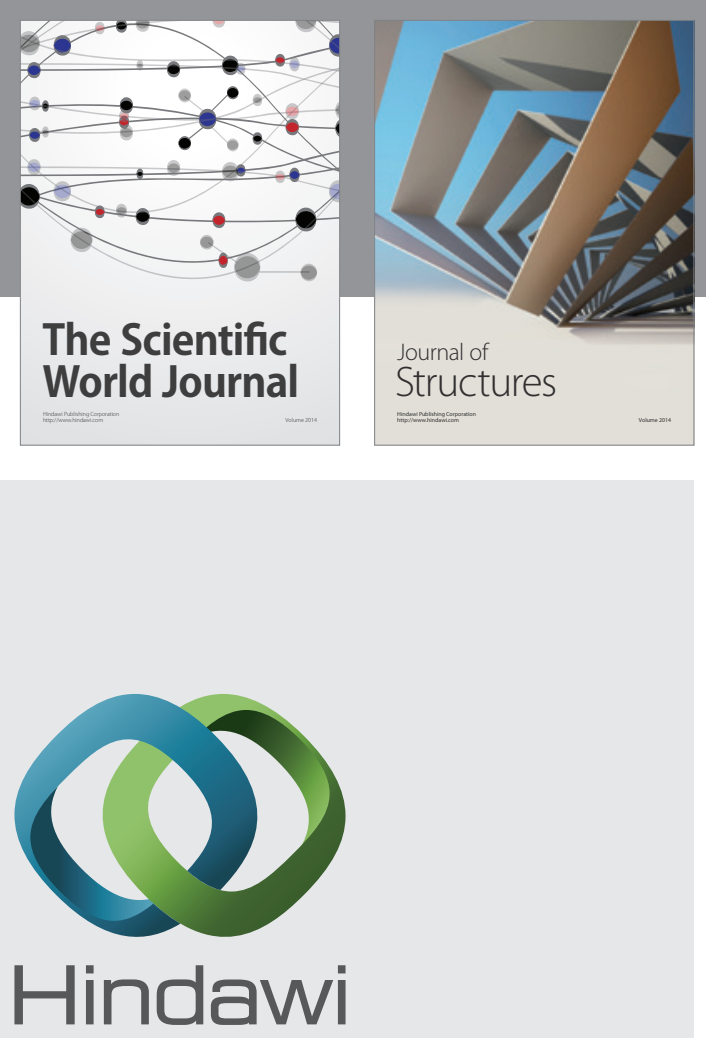

Submit your manuscripts at

http://www.hindawi.com
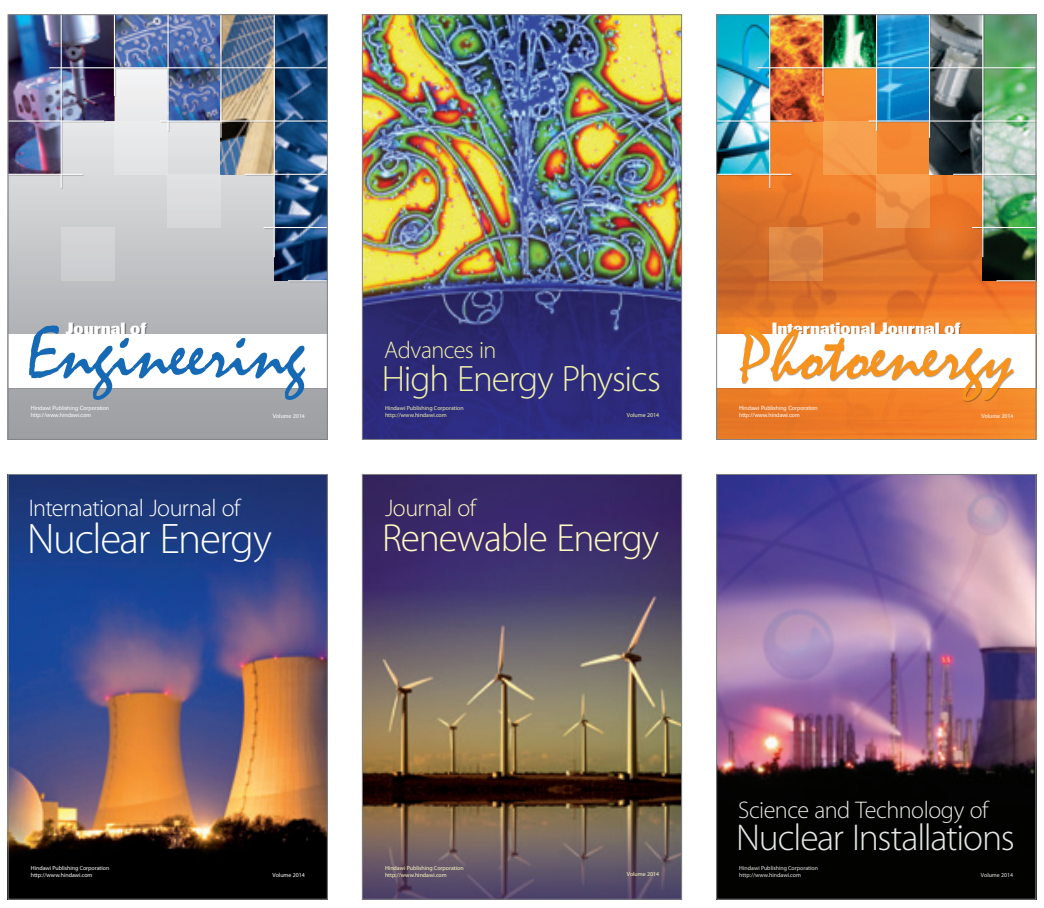
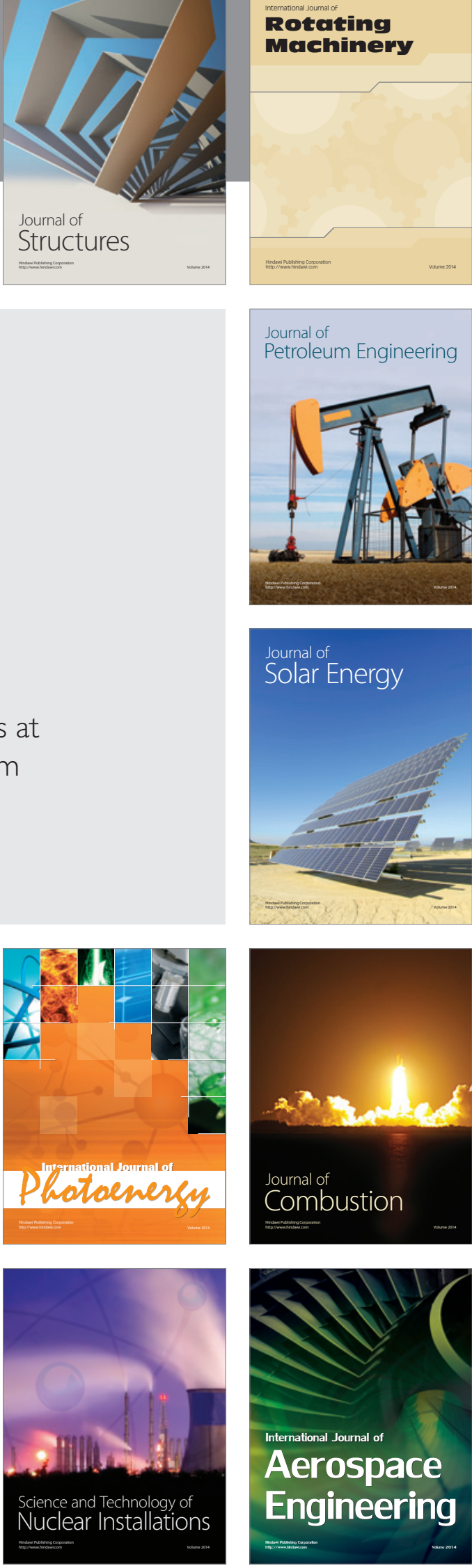